\title{
In vitro antioxidant, anti-inflammatory, and anticancer activities of methanolic extract and its metabolites of whole plant Cardiospermum canescens Wall
}

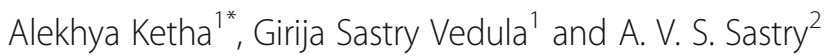

\begin{abstract}
Background: Traditionally, the whole plant of Cardiospermum canescens has wide applications in the management of oxidative stress and inflammation in Africa and Asia. The present study investigated the antioxidant, antiinflammatory, xanthine oxidase (XO) inhibitory, and anticancer activities of metabolites present in the crude methanolic extract of whole plant C. canescens (CCE).

Results: Chemical examination of CCE revealed the presence of six known compounds (1-6). From the results of in vitro studies, it can confirm that CCE exhibited notably inhibition of DPPH and superoxide free radicals, along with COX-1, COX-2, 5-LOX, and XO enzymes. Compounds 2 and 3 showed significant inhibition of DPPH and superoxide free radicals. Also, compound 2 exhibited good inhibition of COX-1 and COX-2 enzyme with $I_{50}$ of 87.0 and $88.0 \mathrm{\mu g} / \mathrm{mL}$. Furthermore, CCE exhibited significant inhibition of 5-LOX and XO enzymes with $\mathrm{IC}_{50}$ of 42.5 and $56.0 \mu \mathrm{g} / \mathrm{mL}$, respectively, while standard with $\mathrm{IC}_{50}$ of 42.5 and $56.0 \mu \mathrm{g} / \mathrm{mL}$, respectively. Among the test series of cancer cell lines, compounds 2, 3, and CCE showed a significant percentage of cell growth lysis of DLD-1 with IC $\mathrm{C}_{50}$ values of 52.5, 72.5, and $32.5 \mu \mathrm{g} / \mathrm{mL}$, respectively. Besides, all the metabolites and CCE showed a very weak degree of specificity against NHME, indicates less toxicity to normal cells.

Conclusion: To conclude, the results of the present study indicated that the methanolic extract from the whole plant of $C$. canescens displayed antioxidant activity by inhibiting DPPH and superoxide free radicals; antiinflammatory effects by regulating enzymes COX-1, COX-2, 5-LOX, and XO; and anticancer activity by inhibiting the growth of MCF-7, DLD-1, HeLa, and A549. These activities can link to natural active compounds 2 and 3. This study supports the traditional uses of the root of $C$. canescens. These data findings suggest that $C$. canescens can be a promising natural source of biological medicines for oxidative stress, inflammation, gout, and cancer.
\end{abstract}

Keywords: Cardiospermum canescens, DPPH, Superoxide, Cyclooxygenase, 5-Lipoxygenase, Xanthine oxidase, Sulforhodamine B assay

\footnotetext{
* Correspondence: alekhya.illa92@gmail.com

${ }^{1}$ Pharmaceutical Chemistry Department, AU College of Pharmaceutical

Sciences, Andhra University, Visakhapatnam 03, India

Full list of author information is available at the end of the article
}

(c) The Author(s). 2020 Open Access This article is licensed under a Creative Commons Attribution 4.0 International License, which permits use, sharing, adaptation, distribution and reproduction in any medium or format, as long as you give appropriate credit to the original author(s) and the source, provide a link to the Creative Commons licence, and indicate if changes were made. The images or other third party material in this article are included in the article's Creative Commons licence, unless indicated otherwise in a credit line to the material. If material is not included in the article's Creative Commons licence and your intended use is not permitted by statutory regulation or exceeds the permitted use, you will need to obtain permission directly from the copyright holder. To view a copy of this licence, visit http://creativecommons.org/licenses/by/4.0/. 


\section{Background}

Cardiospermum is the sole genus of the tropical family Sapindaceae, which records in the flora of Africa and Asia. Cardiospermum genus comprises about 30 species across the globe; most of them are reported to be existing in India. Among these, Cardiospermum canescens is a climber, commonly termed as "Love in a puff" and "Balloon plant." [1] In the folklore of India and some other Asian countries, the whole plant of Cardiospermum species has been used in the treatment of swelling and tumors. Especially, the tribes of Africa and Asia used the whole plant of Cardiospermum in the management of rheumatoid arthritis [1,2]. Also, in the rural areas of Tamil Nadu state, India, the whole plant is used as a leafy vegetable for daily consumption $[2,3]$.

Biologically, the whole plant of $C$. canescens reported for arthritis, lumbago, neuropathy, fever, stiffness of limbs, piles, nervous disorders, neuropathy, diaphoretic, snake bites, laxative, diuretic, emmenagogue, and mucilaginous [4]. Earlier, a series of phytochemical constituents, namely flavonoids, triterpenoids, saponins, carbohydrates, proteins, alkaloids, and tannins was identified from C. canescens [4, 5]. To date, antioxidant, antibacterial, hepatoprotective effects, and cytotoxicity activities were investigated on $C$. canescens $[1,3,5,6]$. Besides, no chemical investigation has attempted to evaluate the chemical constituents of $C$. canescens. So, the present research study mainly aimed to analyze the chemical composition of the crude methanolic extract of whole plant $C$. canescens (CCE) employing chromatography and to monitor antioxidant, xanthine oxidase (XO) inhibitory, anti-inflammatory, and anticancer activities of isolated metabolites and CCE.

\section{Methods}

\section{Plant material}

The whole plant of Cardiospermum canescens Wall (Family: Sapindaceae) was collected in Tirupathi Seshachalam hills, Tirupati, Andhra Pradesh, India, in February 2019. Dr. K. Madhava Chetty of Faculty of Sri Venkateswara University (SVU), Tirupati, Andhra Pradesh, India, has authenticated the sample and a voucher specimen with accession number PS-2019-225 which has been deposited at the Department of Botany, SVU, Tirupati, Andhra Pradesh, India.

\section{Reagents}

Diclofenac, 5-lipoxygenase (5-LO), trichloroacetic acid (TCA), xanthine, and xanthine oxidase (XO) were purchased from Sigma Aldrich (USA). Cyclooxygenase 1 and Cyclooxygenase 2 (COX-1 and COX-2; no. 560131) purchased from Cayman (USA). Other chemicals were of analytical grade.

\section{Extraction and isolation of compounds from whole plant C. canescens}

The whole plant $C$. canescens $(1.0 \mathrm{~kg})$ was dried and powdered and extracted thrice with methanol (96\%) at $25^{\circ} \mathrm{C}$ (3 times $\times 3$ days/time). The obtained fractions were evaporated under vacuum to obtain a methanolic extract of C. canescens (CCE, $45 \mathrm{~g}, 4.5 \% \mathrm{w} / \mathrm{w}$ ).

The CCE extract $(50 \mathrm{~g})$ was exposed to silica gel (\#100-200) column chromatography (CC) through a step gradient of hexane/ethyl acetate solvent, which yielded five main fractions (FI-FV). FI (2 g) subjected to CC (\#100-200) against $n$-hexane/ethyl acetate (step gradient) yielded 1 (110 mg) as a yellowish solid. By using CC (\#100-200), FII (2.5 g) with dichloromethane/ethyl acetate solvent system (step gradient) obtained $2(115 \mathrm{mg})$ as a pale yellow solid, and $3(110 \mathrm{mg})$ as a white powder. Similarly, FIII $(800 \mathrm{mg})$ yielded $4(80 \mathrm{mg})$ as a grayish solid, FIV (1.0 g) yielded $5(100 \mathrm{mg})$ as a greenish semisolid, and FIV (1.2 g) yielded 6 (120 mg) as a pale brownish solid.

\section{Antioxidant activity DPPH assay}

The metabolites (1-6) and CCE were subjected to 1,1diphenyl-2-picrylhydrazyl (DPPH) assay [7] in triplicate. Known concentrations of the sample added $0.004 \%$ $\mathrm{DPPH}$ in methanol. After that, it was incubated at $37^{\circ} \mathrm{C}$ for half an hour and recorded for absorbance at $517 \mathrm{~nm}$ against the blank using UV-visible spectrophotometry (Spectra MAX plus 384, USA).

\section{Superoxide radical scavenging assay}

The metabolites (1-6) and CCE were subjected to scavenging assay of superoxide [8] in triplicate. Known concentrations of the sample added $1 \mathrm{~mL}$ of a standardized solution containing $50 \mu \mathrm{M} \mathrm{NBT}+73 \mu \mathrm{M} \mathrm{NADH}+$ $15 \mu \mathrm{M}$ of PMS in phosphate buffer ( $\mathrm{pH} 7.4$ ) and incubated for $30 \mathrm{~min}$. After that, absorbance was recorded at $562 \mathrm{~nm}$ against the blank.

\section{In vitro assays of anti-inflammatory activity Cyclooxygenase (COX-1 and COX-2) inhibitory assay} By COX inhibitor screening assay kit (Cayman Chemical Company, MI), metabolites (1-6), and CCE were estimated for inhibitory activities of COX [9]. Diclofenac and different concentrations of extracts were used as inhibitor sources. The prostaglandin $2 \alpha$ amount obtained from COX-1 and COX-2 employing substrate arachidonic acid was estimated by using the enzyme immunoassay (EIA) of the same kit. This inhibitory assay performed thrice and their $\mathrm{IC}_{50}$ values attained by analysis of linear regression. 


\section{5-Lipoxygenase inhibitory assay}

The 5-lipoxygenase (5-LOX) activity [10] on linoleic acid was partly disrupted by using a series of metabolites (16) and CCE concentrations. By the end of the reaction time, the absorbances of reaction mixtures were determined at $234 \mathrm{~nm}$ and the $\mathrm{IC}_{50}$ was then calculated. This inhibitory assay was performed thrice with Quercetin as a standard.

\section{Xanthine oxidase inhibitory activity assay}

The XO inhibitory activity [11] determined according to a described method with slight modifications. Briefly, to $10 \mu \mathrm{l}$ of $5 \mathrm{mM}$ xanthine (substrate), $470 \mu \mathrm{l}$ of sodium phosphate buffer of $\mathrm{pH}$ 8.0, $10 \mu \mathrm{l}$ of the sample (metabolites (1-6) and CCE) was dissolved in DMSO, and $10 \mu \mathrm{l}$ of enzyme $\mathrm{XO}$ was added and mixed in the well, then incubated for $5 \mathrm{~min}$ at $25^{\circ} \mathrm{C}$. Later, absorbance was noted at $295 \mathrm{~nm}$. Allopurinol and DMSO were used as standard and control. This inhibitory assay was performed thrice, and their $\mathrm{IC}_{50}$ values were obtained by plotting concentration against respective percentage inhibition.

\section{In vitro anticancer assay}

\section{Sulforhodamine B colorimetric assay}

The in vitro anticancer activity of metabolites (1-6) and CCE was determined by Sulforhodamine B (SRB) assay [12] using four cancer cell lines-MCF-7 (Breast), DLD1 (Colon), HeLa (Cervical), and A549 (Lung)-and one normal human cell line-normal human mammary epithelial (NHME) (provided by National Centre for Cell Science, Pune). All cell lines were maintained and sampling was prepared according to the procedures of Tatipamula et al. [12]. To $190 \mu \mathrm{L}$, screened ideal cell suspension was added to known concentrations of the sample and incubated for $3 \mathrm{~h}$ at $37^{\circ} \mathrm{C}$ with $90 \%$ relative humidity and in the presence of $5 \% \mathrm{CO}_{2}$. After that, $100 \mu \mathrm{L}$ cold TCA was added and again incubate for $1 \mathrm{~h}$ at $4{ }^{\circ} \mathrm{C}$. Then, the entire 96-well plate is washed and airdried at $25^{\circ} \mathrm{C}$. Then, add $100 \mu \mathrm{L}$ SRB solution $(0.057 \%)$; after $30 \mathrm{~min}$, rinse with $1 \% \mathrm{CH}_{3} \mathrm{COOH}$ and add $200 \mu \mathrm{L}$ Tris base $(10 \mathrm{mM}, \mathrm{pH} 10.5)$ solution; and shake for 5 min; absorbance was measured at $510 \mathrm{~nm}$ against a blank (contains the only medium).

\section{Statistical analysis}

All in vitro assay test results were note as mean $\pm \mathrm{SD}$. A one-way analysis of variance (ANOVA) was followed by a $t$ test with $p<0.05$ measured to be statistically significant.

\section{Results}

Chemistry

For the first time, six known compounds (1-6) were identified from the methanolic extract of C. canescens (CCE) utilizing chromatographic methods and analyses of spectral data namely ${ }^{1} \mathrm{H}$ NMR, MS, IR, and ${ }^{13} \mathrm{C}$ NMR

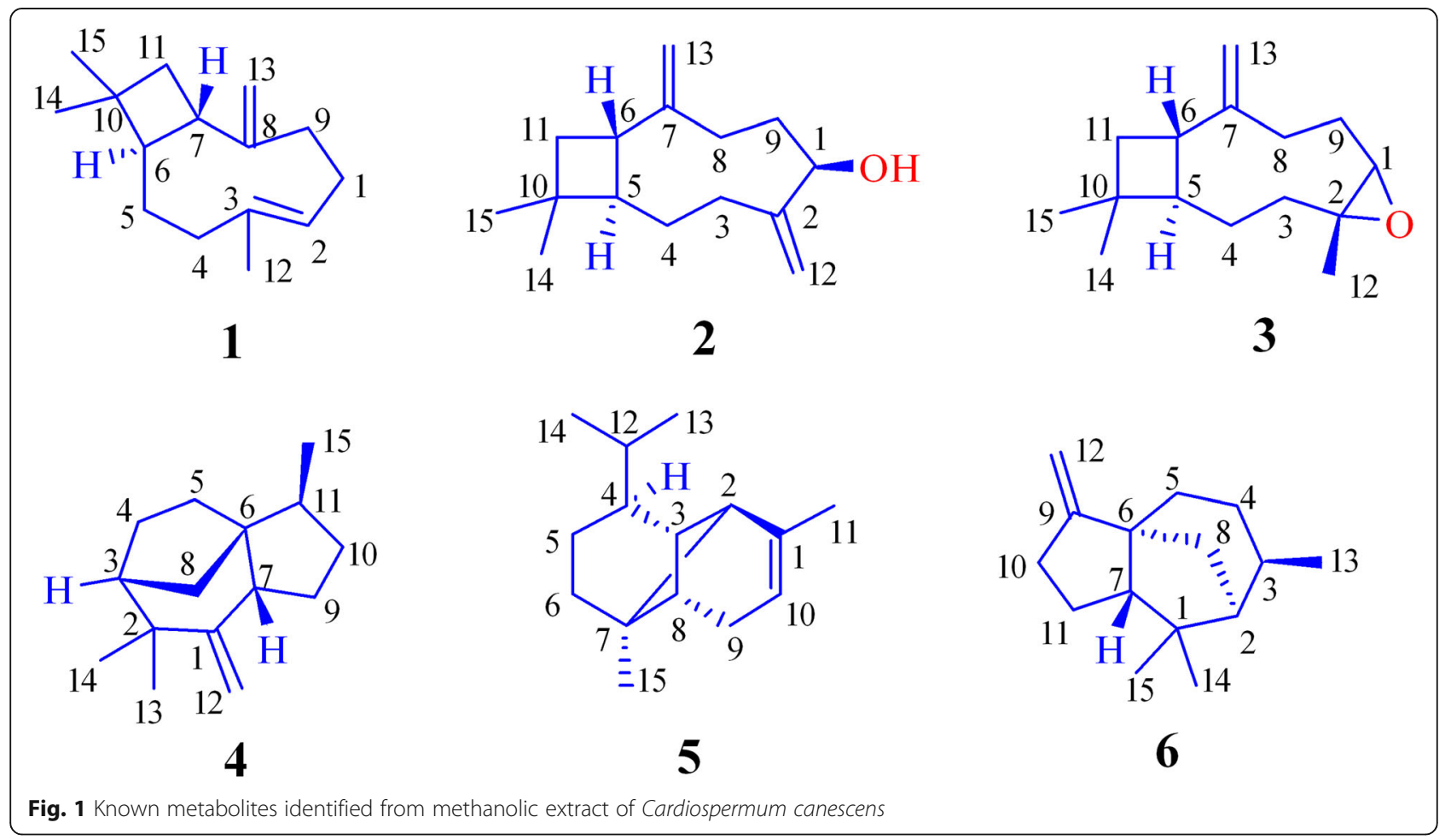


(see supplemental file) and correlated with those reported in the literature (Fig. 1).

Compound 1 [(1R,9S,Z)-4,11,11-trimethyl-8-methylenebicyclo[7.2.0]undec-4-ene] was obtained as a yellowish solid with $R_{\mathrm{f}}$ value of 0.8 in hexane and ethyl acetate (4: 1). Mol. formula: $\mathrm{C}_{15} \mathrm{H}_{24}$. Purity: above $95 \%$ pure (based on TLC and NMR observations). ${ }^{1} \mathrm{H}$ NMR $(400 \mathrm{MHz}$, $\left.\mathrm{CDCl}_{3}\right)$ : $0.986(\mathrm{~s}, 6 \mathrm{H}), 1.083-1.127(\mathrm{~m}, 1 \mathrm{H}), 1.334-1.378$ $(\mathrm{m}, 1 \mathrm{H}), 1.685-1.687(\mathrm{~m}, 4 \mathrm{H}), 1.955-1.993(\mathrm{~m}, 3 \mathrm{H})$, $1.993-2.157(\mathrm{~m}, 4 \mathrm{H}), 2.510-2.520(\mathrm{~d}, 1 \mathrm{H}, J=4 \mathrm{~Hz})$, $2.922(\mathrm{~s}, 1 \mathrm{H}), 4.605-4.609(\mathrm{~d}, 1 \mathrm{H}, J=0.8 \mathrm{~Hz}), 4.855-$ $4.857(\mathrm{~d}, 1 \mathrm{H}, J=0.8 \mathrm{~Hz}), 5.162-5.189(\mathrm{~m}, 1 \mathrm{H}) ;{ }^{13} \mathrm{C} \mathrm{NMR}$ $\left(400 \mathrm{MHz}, \mathrm{CDCl}_{3}\right): 22.21$ (C-12), 27.42 (C-5), 29.29 (C14/15), 30.86 (C-1), 36.82 (C-9/10), 40.13 (C-4), 42.29 (C-11), 51.61 (C-7), 54.52 (C-6), 114.13 (C-13), 126.83 (C-2), 137.31 (C-3), 154.90 (C-8). ESI-MS (positive mode) $m / z: 205\left[\mathrm{M}+\mathrm{H}^{+}\right]$, calcd. $m / z$ for $\mathrm{C}_{15} \mathrm{H}_{24}: 204.19$ [M]. FT-IR (in KBR): 757.67, 830.97, 1037.70, 1088.51, $1129.48,1160.81,1239.96,1342.80,1420.75,1455.71$, $1503.45,1581.58,1619.37,1657.04,2864.85,2926.91$, $2958.57 \mathrm{~cm}^{-1}$.

Compound 2 [(1S,5R,9R)-10,10-dimethyl-2,6-dimethylenebicyclo[7.2.0] undecan-5-ol] was obtained as a pale yellow solid with $R_{\mathrm{f}}$ value of 0.4 in chloroform and ethyl acetate (3:7). Mol. formula: $\mathrm{C}_{15} \mathrm{H}_{24} \mathrm{O}$. Purity: above $95 \%$ pure (based on TLC and NMR observations). ${ }^{1} \mathrm{H}$ NMR $\left(400 \mathrm{MHz}, \mathrm{CDCl}_{3}\right): 0.944(\mathrm{~s}, 6 \mathrm{H}), 1.044-1.082(\mathrm{~m}, 1 \mathrm{H})$, $1.295-1.320(\mathrm{~m}, 1 \mathrm{H}), 1.320-1.333(\mathrm{~m}, 1 \mathrm{H}), 1.532-1.543$ $(\mathrm{m}, 2 \mathrm{H}), 1.613-1.635(\mathrm{~m}, 1 \mathrm{H}), 1.783-1.882(\mathrm{~m}, 1 \mathrm{H})$, $1.902-1.926(\mathrm{~m}, 1 \mathrm{H}), 2.013-2.038(\mathrm{~m}, 2 \mathrm{H}), 2.116-2.141$ $(\mathrm{m}, 2 \mathrm{H}), 2.444-2.504(\mathrm{~m}, 1 \mathrm{H}), 2.992(\mathrm{~s}, 1 \mathrm{H},-\mathrm{OH})$, $4.563-4.567(\mathrm{dd}, 2 \mathrm{H}, J=0.8 \mathrm{~Hz}), 4.813-4.817(\mathrm{dd}, 2 \mathrm{H}, J$ $=0.8 \mathrm{~Hz}) ;{ }^{13} \mathrm{C}$ NMR $(400 \mathrm{MHz}, \mathrm{CDCl} 3): 22.80$ (C-4), 24.05 (C-14/15), 28.98 (C-3), 29.56 (C-8), 30.03 (C-9), 31.59 (C-10), 37.06 (C-11), 46.37 (C-6), 49.29 (C-5), 72.64 (C-1), 107.12 (C-12), 108.74 (C-13), 147.5 (C-2), 147.87 (C-7). ESI-MS (positive mode) $\mathrm{m} / z: 221[\mathrm{M}+$ $\mathrm{H}^{+}$], calcd. $m / z$ for $\mathrm{C}_{15} \mathrm{H}_{24} \mathrm{O}: 220.18$ [M]. FT-IR (in KBR): 758.70, 1462.79, 28.55.53, $2921.95 \mathrm{~cm}^{-1}$.

Compound 3 [(1R,4R,10S)-4,12,12-trimethyl-9-methylene-5-oxatricyclo[8.2.0.04,6] dodecane] was obtained as a white powder with $R_{\mathrm{f}}$ value of 0.6 in hexane and ethyl acetate (1:1). Mol. formula: $\mathrm{C}_{15} \mathrm{H}_{24} \mathrm{O}$. Purity: above $95 \%$ pure (based on TLC and NMR observations). ${ }^{1} \mathrm{H}$ NMR $\left(400 \mathrm{MHz}, \mathrm{CDCl}_{3}\right): 0.960$ (s, 6H), 1.160 (s, 3H), 1.239$1.279(\mathrm{~m}, 4 \mathrm{H}), 1.389-1.630(\mathrm{~m}, 2 \mathrm{H}), 1.647-1.691(\mathrm{~m}$, $2 \mathrm{H}), 1.898-1.942(\mathrm{~m}, 1 \mathrm{H}), 2.054-2.175(\mathrm{~m}, 2 \mathrm{H}), 2.190-$ $2.205(\mathrm{~m}, 1 \mathrm{H}), 2.461-2.519(\mathrm{~m}, 1 \mathrm{H}), 4.829-4.831(\mathrm{dd}$, $2 \mathrm{H}, J=0.8 \mathrm{~Hz}) ;{ }^{13} \mathrm{C}$ NMR $(400 \mathrm{MHz}, \mathrm{CDCl} 3): 22.87$ (C12), 27.28 (C-4), 32.01 (C-9), 32.22 (C-14/15), 38.07 (C8), 39.75 (C-10), 40.40 (C-3), 45.22 (C-11), 54.54 (C-6), 59.44 (C-5), 65.15 (C-2), 67.48 (C-1), 116.90 (C-13), 156.03 (C-7). ESI-MS (positive mode) $\mathrm{m} / z: 221[\mathrm{M}+$ $\mathrm{H}^{+}$], calcd. $m / z$ for $\mathrm{C}_{15} \mathrm{H}_{24} \mathrm{O}: 220.18$ [M]. FT-IR (in
KBR): $757.43, \quad 1164.22, \quad 1243.88, \quad 1280.23, \quad 1371.49$, 1462.62, 1625.60, 2855.31, $2920.71 \mathrm{~cm}^{-1}$.

Compound 4 [(3S,3aS,6R,8aS)-3,7,7-trimethyl-8-methyleneoctahydro- $1 \mathrm{H}-3 \mathrm{a}, 6$-methanoazulene] was obtained as a grayish solid with $R_{\mathrm{f}}$ value of 0.4 in hexane and ethyl acetate (1:1). Mol. formula: $\mathrm{C}_{15} \mathrm{H}_{24}$. Purity: above $95 \%$ pure (based on TLC and NMR observations). ${ }^{1} \mathrm{H}$ NMR (400 MHz, $\left.\mathrm{CDCl}_{3}\right): 0.893-0.918(\mathrm{~m}, 1 \mathrm{H}), 1.053-1.066(\mathrm{~d}$, $3 \mathrm{H}, J=5.2 \mathrm{~Hz}), 1.144-1.169(\mathrm{~m}, 1 \mathrm{H}), 1.292-1.298(\mathrm{~m}$, $1 \mathrm{H}), 1.386(\mathrm{~s}, 6 \mathrm{H}), 1.433-1.438(\mathrm{~m}, 2 \mathrm{H}), 1.486-1.515(\mathrm{~m}$, $1 \mathrm{H}), 1.543-1.574(\mathrm{~m}, 2 \mathrm{H}), 1.568-1.574(\mathrm{~m}, 1 \mathrm{H}), 1.660$ $1.687(\mathrm{~m}, 2 \mathrm{H}), 2.071-2.106(\mathrm{t}, 2 \mathrm{H}, J=6.8,7.2 \mathrm{~Hz}), 4.975-$ $4.980(\mathrm{dd}, 2 \mathrm{H}, J=0.8 \mathrm{~Hz}) ;{ }^{13} \mathrm{C}$ NMR $\left(400 \mathrm{MHz}, \mathrm{CDCl}_{3}\right)$ : 12.17 (C-15), 21.42 (C-9), 23.62 (C-13/14), 23.77 (C-4), 28.97 (C-10), 34.26 (C-5), 35.55 (C-2), 38.14 (C-8/11), 43.31 (C-7), 43.50 (C-3), 52.69 (C-6), 101.50 (C-12), 156.57 (C-1). ESI-MS (positive mode) $\mathrm{m} / z: 205\left[\mathrm{M}+\mathrm{H}^{+}\right]$, calcd. $m / z$ for $\mathrm{C}_{15} \mathrm{H}_{24}: 204.19$ [M]. FT-IR (in KBR): 758.59, 1466.21, 2853.30, $2919.84 \mathrm{~cm}^{-1}$.

Compound 5 [(1R,2S,6S,7S,8S)-8-isopropyl-1,3-dimethyltricyclo[4.4.0.02,7]dec-3-ene] was obtained as a greenish semi-solid with $R_{\mathrm{f}}$ value of 0.6 in chloroform and ethyl acetate (3:7). Mol. formula: $\mathrm{C}_{15} \mathrm{H}_{24}$. Purity: above $95 \%$ pure (based on TLC and NMR observations). ${ }^{1} \mathrm{H}$ NMR (400 $\mathrm{MHz}, \mathrm{CDCl}_{3}$ ): $1.044(\mathrm{~s}, 3 \mathrm{H}), 1.057$ (s, 3H), 1.061 (s, 3H), $1.215-1.318(\mathrm{~m}, 1 \mathrm{H}), 1.326-1.331(\mathrm{~m}, 1 \mathrm{H}), 1.409-1.434(\mathrm{~m}$, $2 \mathrm{H}), 1.488-1.512(\mathrm{~m}, 1 \mathrm{H}), 1.606-1.755(\mathrm{~m}, 2 \mathrm{H}), 1.811-$ $1.871(\mathrm{~m}, 2 \mathrm{H}), 1.912(\mathrm{~s}, 1 \mathrm{H}), 1.913(\mathrm{~s}, 3 \mathrm{H}), 2.050-2.093(\mathrm{~m}$, $1 \mathrm{H}), 5.529(\mathrm{t}, 1 \mathrm{H}, J=0.8 \mathrm{~Hz}) ;{ }^{13} \mathrm{C}$ NMR $\left(400 \mathrm{MHz}, \mathrm{CDCl}_{3}\right)$ : 22.26 (C-5/13/14), 25.62 (C-15), 26.07 (C-11), 30.44 (C-12), 33.80 (C-9), 38.10 (C-6), 39.41 (C-7), 44.84 (C-8), 46.31 (C4), 47.30 (C-3), 49.31 (C-2), 120.87 (C-10), 143.44 (C-1). ESI-MS (positive mode) $m / z: 205\left[\mathrm{M}+\mathrm{H}^{+}\right]$, calcd. $m / z$ for $\mathrm{C}_{15} \mathrm{H}_{24}: 204.19$ [M]. FT-IR (in KBR): 757.07, 831.97, $1036.44,1089.60,1130.24,1160.95,1258.86,1344.88$, $1419.78,1455.32,1505.34,1580.19,1621.23,1653.08$, 2875.04, $2962.67 \mathrm{~cm}^{-1}$.

Compound 6 [(3aR,6R,7S,8aS)-6,8,8-trimethyl-3-methyleneoctahydro- $1 \mathrm{H}-3 \mathrm{a}, 7$-methanoazulene] was obtained as a pale brownish solid with $R_{\mathrm{f}}$ value of 0.4 in chloroform and ethyl acetate (1:1). Mol. formula: $\mathrm{C}_{15} \mathrm{H}_{24}$. Purity: above 95\% pure (based on TLC and NMR observations). ${ }^{1} \mathrm{H}$ NMR $\left(400 \mathrm{MHz}, \mathrm{CDCl}_{3}\right): 0.880-0.893$ (s, $3 \mathrm{H}, J=5.2 \mathrm{~Hz}), 0.937(\mathrm{~s}, 6 \mathrm{H}), 1.061-1.069(\mathrm{~m}, 2 \mathrm{H})$, $1.111-1.166(\mathrm{~m}, 1 \mathrm{H}), 1.175-1.180(\mathrm{~m}, 2 \mathrm{H}), 1.185-$ $1.189(\mathrm{~m}, 1 \mathrm{H}), 1.362-1.368(\mathrm{~m}, 1 \mathrm{H}), 1.387-1.429(\mathrm{~m}$, $4 \mathrm{H}), 2.054-2.092(\mathrm{~d}, 2 \mathrm{H}, J=15.2 \mathrm{~Hz}), 4.587-4.595(\mathrm{t}$, $1 \mathrm{H}, J=0.8,2.4 \mathrm{~Hz}) ;{ }^{13} \mathrm{C} \mathrm{NMR}\left(400 \mathrm{MHz}, \mathrm{CDCl}_{3}\right)$ : 22.03 (C-13), 26.08 (C-14/15), 29.07 (C-11), 30.59 (C3), 32.88 (C-4), 35.35 (C-10), 35.44 (C-5), 37.96 (C-8), 46.59 (C-1), 52.74 (C-6), 56.18 (C-2), 60.45 (C-7), 100.53 (C-12), 157.13 (C-9). ESI-MS (positive mode) $m / z: 205\left[\mathrm{M}+\mathrm{H}^{+}\right]$, calcd. $m / z$ for $\mathrm{C}_{15} \mathrm{H}_{24}: 204.19$ [M]. FT-IR (in KBR): 699.83, 805.16, 849.70, 1163.13, 
1205.87, 1268.76, 1321.28, 1447.21, 1499.94, 1625.06, 2857.43, 2921.21, $3356.81 \mathrm{~cm}^{-1}$.

\section{Antioxidant activity}

Initially, $\mathbf{C C E}$ was exposed to an initial test against $\mathrm{DPPH}$ [7] and superoxide [8] assays, and its $\mathrm{IC}_{50}$ values were found to be 60.0 and $62.5 \mu \mathrm{g} / \mathrm{mL}$, respectively, whereas standard (ascorbic acid) value was 27.8 and $32.1 \mu \mathrm{g} / \mathrm{mL}$, respectively. Based on the preliminary antioxidant analysis of CCE, we subjected its metabolites (1-6) for antioxidant activity. Among all the tested compounds, only compounds $\mathbf{2}$ and $\mathbf{3}$ showed moderate inhibition of DPPH and superoxide free radicals. The concentration of 2 needed for 50\% inhibition of DPPH and superoxide free radicals was found to be 169.0 and $180.0 \mu \mathrm{g} / \mathrm{mL}$, respectively, while 3 with 285.0 and $230.0 \mu \mathrm{g} / \mathrm{mL}$, respectively (Fig. 2).

\section{Anti-inflammatory activity}

The anti-inflammatory effect of metabolites (1-6) and CCE were evaluated based on their inhibitory activities against COX-1 and 2 [9], 5-LOX [10] and XO [11] enzymes, initially at $100 \mu \mathrm{g} / \mathrm{mL}$ concentration. During initially screening, CCE showed better inhibitor profile against COX-1, COX-2, 5-LOX, and XO enzymes with $72.50 \pm 3.44,80.80 \pm 4.30,70.67 \pm 4.57$, and $75.90 \pm$ 4.25 \%enzyme inhibition, respectively. Besides, among the metabolites, only compound 2 at $100 \mu \mathrm{g} / \mathrm{mL}$ concentration displayed significant inhibitory profile on particularly COX -1 and 2 enzymes with $58.17 \pm 3.67$ and 56.50 $\pm 4.50 \%$ enzyme inhibition, respectively. Hence, the active samples, i.e., compound 2 and CCE, are further examined at 25, 50, 75, and $100 \mu \mathrm{g} / \mathrm{mL}$ concentrations with standard drugs (indomethacin, diclofenac, and allopurinol) at 2.5, 5.0, 7.5, and $10.0 \mu \mathrm{g} / \mathrm{mL}$ concentrations. From the obtained results, $\mathrm{IC}_{50}$ values calculated by plotting concentration against percentage enzyme inhibition.

The 50\% COX-1 enzyme inhibitory concentration required for compound 2 and CCE was found to be 87.0 and $45.0 \mu \mathrm{g} / \mathrm{mL}$, respectively, whereas indomethacin with $4.2 \mu \mathrm{g} / \mathrm{mL}$ (Fig. 3a). Similarly, the $\mathrm{IC}_{50}$ values of compound 2 and CCE on COX-2 were found to be 88.0 and $63.1 \mu \mathrm{g} / \mathrm{mL}$, respectively, while indomethacin with $4.2 \mu \mathrm{g} / \mathrm{mL}$ (Fig. 3b). The concentration needed for $50 \%$ inhibition of 5-LOX and XO enzymes of CCE was determined to be 42.5 and $56.0 \mu \mathrm{g} / \mathrm{mL}$, respectively, whereas standard drugs (diclofenac and allopurinol) with 2.7 and $2.6 \mu \mathrm{g} / \mathrm{mL}$, (Fig. 3c, d).

\section{Anticancer activity}

Firstly, all the isolated metabolites (1-6) and CCE tested against MCF-7 (breast), DLD-1 (colon), HeLa (cervical), A549 (lung), and normal human mammary epithelial (NHME) cell lines at $100 \mu \mathrm{g} / \mathrm{mL}$ concentration. From the primary screening of SRB assay [12], it noticed that CCE showed a prominent degree of specificity against the tested series of cancer cell lines. At $100 \mu \mathrm{g} / \mathrm{mL}$ concentration, CCE potently inhibited the growth of DLD-1 and A549 with $81.71 \pm 8.53$ and $75.26 \pm 8.55 \%$ cell death, respectively, than standard drug doxorubicin

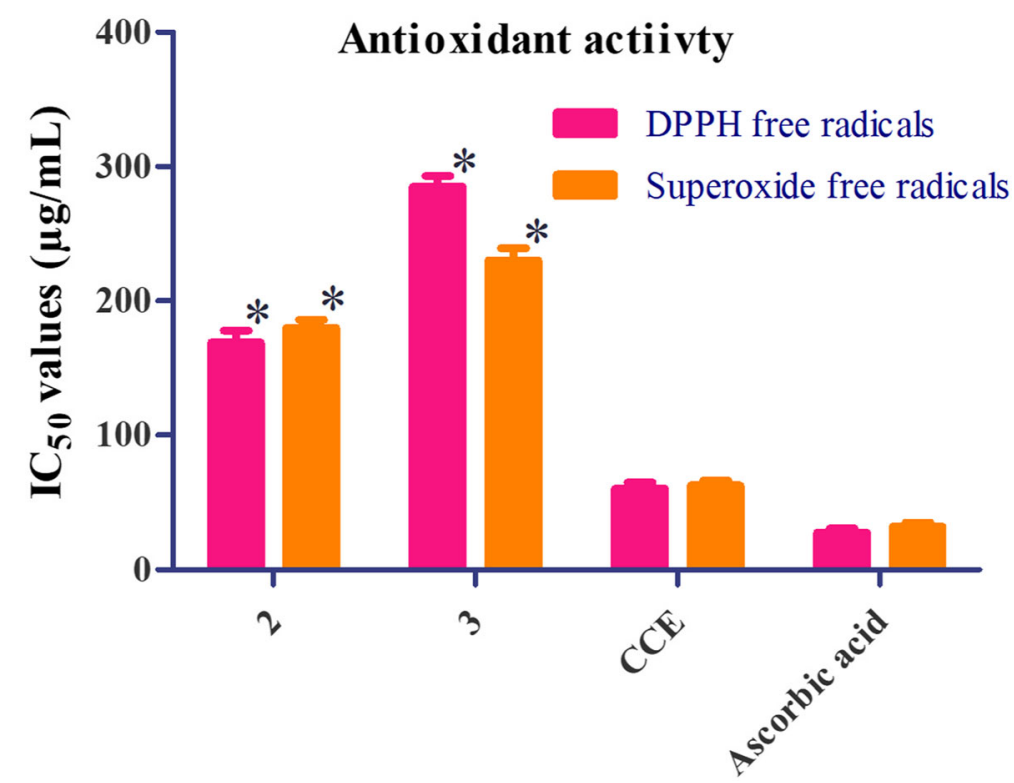

Fig. $2 \mid C_{50}$ values of isolated metabolites and methanolic extract of Cardiospermum canescens (CCE) against DPPH and superoxide free radicals. DPPH, 1,1-diphenyl-2-picrylhydrazyl; $n=3$, mean \pm SD values. Statistical analysis: one-way ANOVA followed by $t$ test. ${ }^{*}$ Statistically significant $(p<0.05)$ between free radicals treatment with compounds and extract 


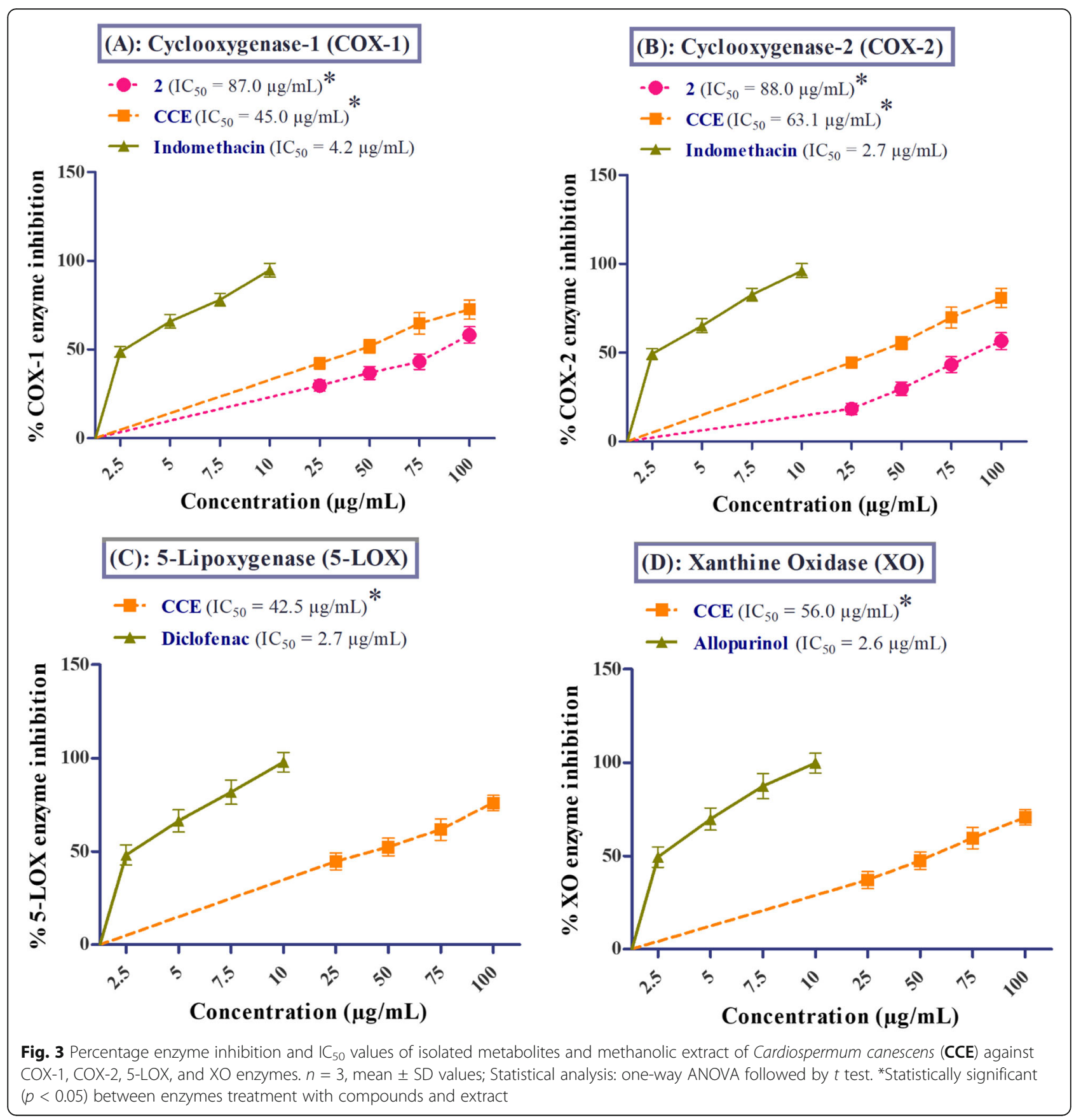

$(10 \mu \mathrm{g} / \mathrm{mL})$ with $76.17 \pm 7.71$ and $69.54 \pm 5.10 \%$ cell death. Besides, metabolite 2 showed a significant degree of specificity against all the tested panel of cancer cell lines, while compound 3 against only DLD-1 and A549 and compound $\mathbf{1}$ against only A549.

Secondly, the samples showed above $50 \%$ of cell death, examined for further analysis at $25,50,75$, and $100 \mu \mathrm{g} / \mathrm{mL}$ concentrations with the standard drug (doxorubicin) at $2.5,5.0,7.5$, and $10.0 \mu \mathrm{g} / \mathrm{mL}$ concentrations. $\mathrm{IC}_{50}$ values calculated by plotting concentration against percentage cell growth inhibition. The
$\mathrm{IC}_{50}$ values of 2 and $\mathrm{CCE}$ on MCF-7 were found to be 82.0 and $61.5 \mu \mathrm{g} / \mathrm{mL}$, respectively, whereas doxorubicin with $3.2 \mu \mathrm{g} / \mathrm{mL}$ (Fig. 4a). The concentration of 2, 3, and CCE needed for $50 \%$ cell death of DLD-1 was found to be $52.5,72.5$, and $32.5 \mu \mathrm{g} / \mathrm{mL}$, respectively, while doxorubicin with $4.2 \mu \mathrm{g} / \mathrm{mL}$ (Fig. 4b). From the results of SRB assay on HeLa, the $\mathrm{IC}_{50}$ values of 2 and CCE were found to be 96.0 and $78.0 \mu \mathrm{g} / \mathrm{mL}$, respectively, whereas doxorubicin with $3.8 \mu \mathrm{g} / \mathrm{mL}$ (Fig. 4c). Similarly, the concentration needed for $50 \%$ cell death of A549 of 1,2, 3, and 


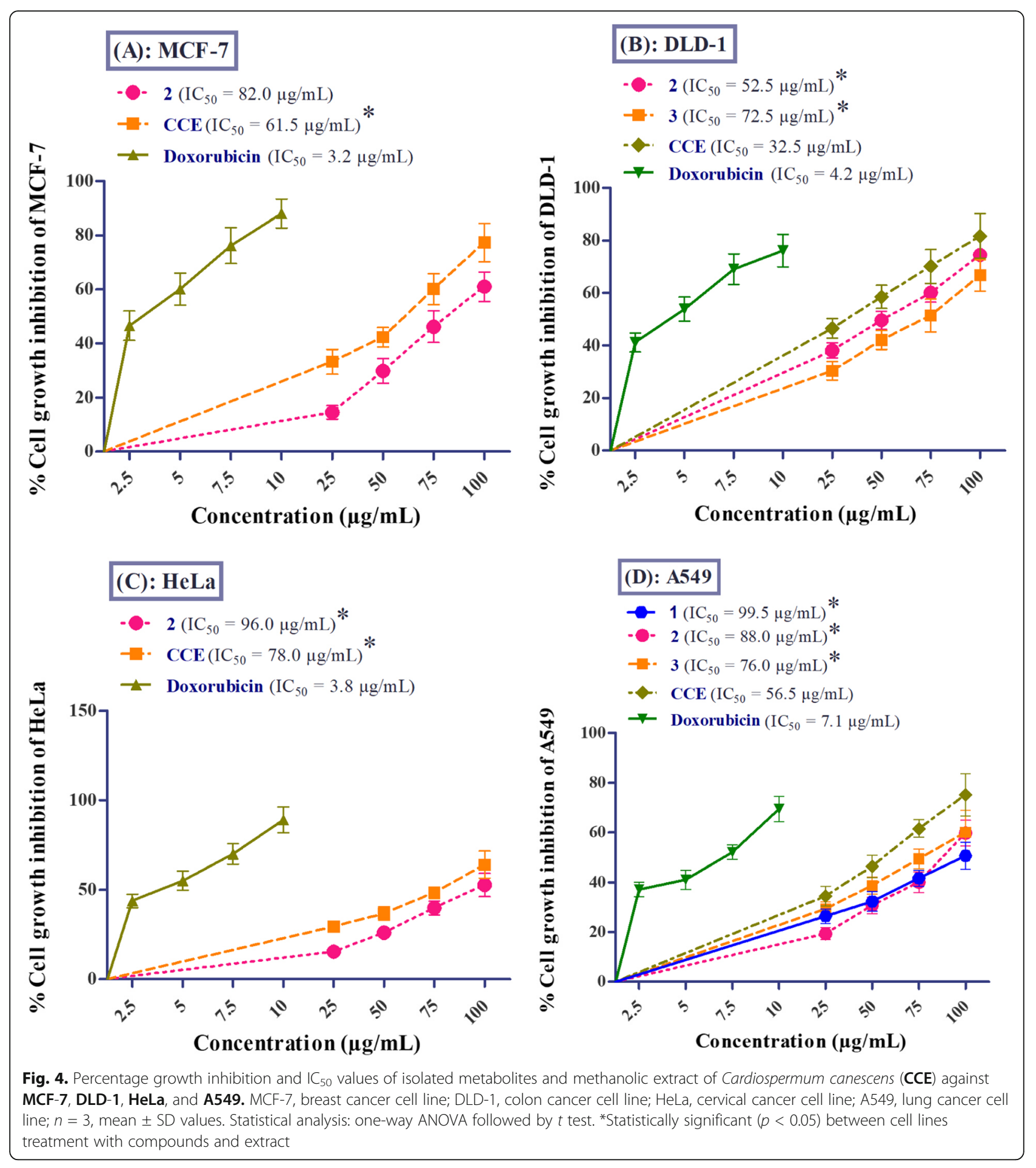

CCE determined to be $99.5,88.0,76.0$, and $56.5 \mu \mathrm{g} /$ $\mathrm{mL}$, respectively, while doxorubicin with $3.8 \mu \mathrm{g} / \mathrm{mL}$ (Fig. 4d). Besides, all the isolated compounds (1-6) and CCE showed a very mild degree of specificity against NHME which indicates that the samples are non-toxic to normal human cells.

\section{Discussion}

In the present study, six known secondary metabolites (1-6) were isolated from the methanolic extract of whole plant C. canescens (CCE). This identification provides new information on the phytochemical profile of C. canescens. Also, the biological profile of $C$. canescens justifies its natural aptitude to act against free radicals, 
inflammation, and cancer. From the DPPH and superoxide free radical assay, it observed that CCE inhibits them prominently. In the deep enzymatic analysis of anti-inflammation proved that the methanolic extract of whole plant C. canescens has potent inhibition of COX-1 and 2, 5-LOX, and XO enzymes. This observation helps to investigate the anticancer ability of $C$. canescens, and the outcomes of SRB assay showed that CCE has a significant degree of specificity against MCF-7, DLD-1, HeLa, and A549.

In general, inflammatory activity was caused by an elevated level of prostaglandins and leukotrienes in the body. Cyclooxygenase (COX-1 and 2) and 5-lipoxygenase (5LOX) enzymes are responsible for the production of prostaglandins and leukotrienes, respectively. Hence, inhibition of COX-1 and 2 by anti-inflammatory drugs such as NSAIDs decrease the production of the prostaglandins, ultimately resulting in the reduction of inflammation, as well as pain [13-15]. Nevertheless, inhibition of particularly prostaglandins can cause activation of 5-LOX pathway alternative, which results in the elevation of proinflammatory and gastro-toxic leukotrienes production. Therefore, drugs that inhibit both COX and 5-LOX (dual inhibitors) reduce leukotrienes and prostaglandin production and completely inhibit inflammation. Also, by using dual inhibitors, the adverse effects on the cardiovascular system caused by selective COX-2 inhibitors (coxibs) will be reduced [16-20]. The results of the present study showed that CCE acted as a dual inhibitor and effectively inhibited both COX and 5-LOX enzymes, whereas compound 2 prominently inhibit particularly COX-1 enzyme.

Generally, uric acid formed from purines xanthine and purines hypoxanthine in the presence of an enzyme called xanthine oxidase (XO). Excess deposition of uric acid in the joints of the human body leads to severe joint pains, which is well known as gout (painful inflammation) [21, 22]. Furthermore, XO is a good biological source for oxygen-containing free radicals that damage living tissues and cause-related inflammatory diseases like aging, cancer, and atherosclerosis. Hence, XO inhibitors play a vital role in diagnosis, not only gout but also related inflammatory diseases [23-25]. This study suggests that only CCE possesses XO inhibitory activity that might be helpful in the management of gout and other inflammatory-related diseases.

Many scientists reported that chronic inflammation is the key causative factor in various types of cancers. Usually, the longer the existence of the inflammation, the greater the risk of cancer. In general, chronic exposure to inflammatory mediators, which include free radicals, cytokines, COX-1, COX-2, and 5-LOX, leads to a sharp rise in mutagenesis, cell proliferation, and oncogene activation eventually leading to the proliferation of cells which lost control over normal growth [26-31]. So, as metabolites and CCE showed good anti-inflammatory properties, we further investigated their anticancer abilities using the SRB assay. From the outcomes, it is justified that compound 2, 3, and CCE have an ability to lysis the cells of MCF-7, DLD-1, HeLa, and A549. Also, all the metabolites and CCE are less toxic towards the human cell lines.

In the folklore, the whole plant of $C$. canescens has applications in managing acute arthritis, rheumatism, inflammation, and cancer in India. The present study scientifically justifies the uses of the $C$. canescens as an antioxidant, anti-inflammatory, and anticancer agent in traditional medicine. The major phytoconstituents in CCE were identified as 1-6. Thus, these active constituents might be responsible for the biological activities of CCE.

\section{Conclusion}

To conclude, the results of the present study indicated that the methanolic extract from the whole plant of $C$. canescens displayed antioxidant activity by inhibiting $\mathrm{DPPH}$ and superoxide free radicals; anti-inflammatory effects by regulating enzymes COX-1, COX-2, 5-LOX, and $\mathrm{XO}$; and anticancer activity by inhibiting the growth of MCF-7, DLD-1, HeLa and A549. The key metabolite responsible for in vitro activities were claimed to be compound $\mathbf{2}$ and $\mathbf{3}$. The results provide evidence that supports the traditional uses of the whole plant of $C$. canescens. Also, these findings suggest that the plant of C. canescens can take an account as a good natural source of remedial medicine for alleviating pain and cancer. However, an in-deep chemical and biological examination is further required to use the natural source (i.e., C. canescens) in the management of oxidative stress conditions, inflammation, gout, and cancer.

\section{Supplementary information}

Supplementary information accompanies this paper at https://doi.org/10. 1186/s43094-020-00028-y.

\footnotetext{
Additional file 1: Figure S1. $1 \mathrm{H} \mathrm{NMR}\left(400 \mathrm{MHz}, \mathrm{CDCl}_{3}\right)$ of compound 1. Figure S2. $13 \mathrm{C} \mathrm{NMR} \mathrm{(400} \mathrm{MHz,} \mathrm{CDCl} 3$ ) of compound 1. Figure S3. ESI-MS (positive mode) of compound 1. Figure S4. FT-IR of compound 1. Figure S5. $1 \mathrm{H} \mathrm{NMR}\left(400 \mathrm{MHz}_{1} \mathrm{CDCl}_{3}\right)$ of compound 2. Figure S6. $13 \mathrm{C}$ NMR $\left(400 \mathrm{MHz}_{2} \mathrm{CDCl}_{3}\right.$ ) of compound 2. Figure S7. ESI-MS (positive mode) of compound $\mathbf{2}$. Figure S8. FT-IR of compound $\mathbf{2}$. Figure $\mathbf{5 9}$. $1 \mathrm{H}$ NMR $\left(400 \mathrm{MHz}_{1} \mathrm{CDCl}_{3}\right.$ ) of compound 3. Figure S10. 13C NMR $(400 \mathrm{MHz}$, $\mathrm{CDCl}_{3}$ ) of compound $\mathbf{3}$. Figure S11. ESI-MS (positive mode) of compound 3. Figure S12. FT-IR of compound 3. Figure S13. $1 \mathrm{H}$ NMR (400 $\mathrm{MHz}_{1} \mathrm{CDCl}_{3}$ ) of compound 4. Figure S14. $13 \mathrm{C} \mathrm{NMR}\left(400 \mathrm{MHz}_{1} \mathrm{CDCl}_{3}\right)$ of compound 4. Figure S15. ESI-MS (positive mode) of compound $\mathbf{4}$. Figure S16. FT-IR of compound 4. Figure S17. $1 \mathrm{H} \mathrm{NMR}\left(400 \mathrm{MHz}_{1} \mathrm{CDCl}_{3}\right)$ of compound 5. Figure S18. $13 \mathrm{C} \mathrm{NMR}\left(400 \mathrm{MHz}, \mathrm{CDCl}_{3}\right)$ of compound 5. Figure S19. ESI-MS (positive mode) of compound 5. Figure S20. FTIR of compound 5. Figure S21. $1 \mathrm{H} \mathrm{NMR}\left(400 \mathrm{MHz}_{1} \mathrm{CDCl}_{3}\right)$ of compound 6. Figure S22. $13 \mathrm{C} \mathrm{NMR} \mathrm{(400} \mathrm{MHz,CDCl}$ ) of compound $\mathbf{6}$. Figure $\mathbf{S 2 3}$. ESI-MS (positive mode) of compound $\mathbf{6}$. Figure S24. FT-IR of compound 6. Table S1. Percentage inhibition and $I C_{50}$ values of $\mathbf{1 - 6}$ and $\mathbf{C C E}$
} 
against DPPH and superoxide free radicals. Table S2. Percentage inhibition and $I_{50}$ values of 1-6 and CCE against Cyclooxygenase (COX-1 \& 2), 5-lipoxygenase (5-LOX) and Xanthine oxidase (XO) enzymes. Table S3. Percentage growth inhibition of 1-6 and CCE on four different cancer cell lines and one normal human cell line.

\section{Abbreviations}

5-LOX: 5-Lipoxygenase; A549: Lung cancer cell line; CC: Column chromatography; CCE: Crude methanolic extract of whole plant Cardiospermum canescens; COX-1: Cyclooxygenase 1; COX-2: Cyclooxygenase 2; DLD-1: Colon cancer cell line; DMSO: Dimethyl sulfoxide; DPPH: 1,1Diphenyl-2-picrylhydrazyl; HeLa: Cervical cancer cell line; MCF-7: Breast cancer cell line; NHME: Normal human mammary epithelial; NMR: Nuclear magnetic resonance; TCA: Trichloroacetic acid; TLC: Thin-layer chromatography; XO: Xanthine oxidase

\section{Acknowledgements}

The authors are thankful to the authorities of the AU College of Pharmaceutical Sciences, Andhra University, for providing the necessary facilities to complete the present work.

\section{Plant source}

The whole plant of Cardiospermum canescens Wall (Family: Sapindaceae) was collected in Tirupathi Seshachalam hills, Tirupati, Andhra Pradesh, India, in February 2019. Dr. K. Madhava Chetty of Faculty of Sri Venkateswara University (SVU), Tirupati, Andhra Pradesh, India, has authenticated the sample and a voucher specimen with accession number PS-2019-225 was deposited at the Department of Botany, SVU, Tirupati, Andhra Pradesh, India.

\section{Studies involving plants}

As per the local and national guidelines and legislation and the required or appropriate permissions and/or licenses for the study.

\section{Authors' contributions}

AK: Research scholar who carried isolation and biological evaluations and was a major contributor in writing the manuscript. GSV: Supervisor who guided in isolation and characterization of the secondary metabolites. AVSS: Professor in pharmacology who proposed and monitored the pharmacological studies. All authors have read and approved the manuscript.

\section{Funding}

No funding was received.

\section{Availability of data and materials}

All data and material are available upon request.

\section{Ethics approval and consent to participate}

Not applicable

\section{Consent for publication}

Not applicable

\section{Competing interests}

No conflict of interest between any of the authors.

\section{Author details}

${ }^{1}$ Pharmaceutical Chemistry Department, AU College of Pharmaceutical Sciences, Andhra University, Visakhapatnam 03, India. ²Pharmacology Department, MR College of Pharmacy, Vizianagaram 02, India.

Received: 3 February 2020 Accepted: 14 April 2020

Published online: 11 May 2020

\section{References}

1. Udhayasankar MR, Danya U, Punitha D, Arumugasamy K (2013) In vitro cytotoxic activity of methanolic extract of Cardiospermum canescens Wall. (Sapindaceae). Research in Pharmacy 3:1-5
2. Shivamanjunath MP, Sreenath KP (2013) Phytochemical studies on Cardiospermum canescens Wall. American International Journal of Research in Formal, Applied and Natural Sciences 3:61-65

3. Udhayasankar MR, Danya U, Punitha D, Arumugasamy K, Shalimol A (2013) In vitro anti-bacterial activity of methanolic extract of Cardiospermum canescens-a wild medicinal plant. Int J Herb Med 1:73-75

4. Silva FL, Moreno PR, Braz-Filho R, Tavares JF, Barbosa-Filho JM (2014) Chemical constituents of Cardiospermum corindum L. and their distribution in Sapindaceae. Biochem Syst Ecol 57:137-140 https://doi.org/10.1016/j.bse. 2014.07.021

5. Udhayasankar MR, Danya U, Punitha D, Arumugasamy K (2013) Antioxidant activity of Cardiospermum canescens Wall. (Sapindaceae)-a wild edible plant from western Ghats. Int J Pharm Pharm Sci 5:322-324

6. Manda RM, Parshaboina VK, Mudideni R, Mydaraboina K (2013) Hepatoprotective effect of Cardiospermum canescens on carbon tetrachloride induced hepatotoxicity in albino rats. Int J Pharm Res Sci 3:64-71

7. Tatipamula VB, Vedula GS, Sastry AV (2019) Chemical and pharmacological evaluation of manglicolous lichen Roccella montagnei Bel em. DD Awasthi. Future. Journal of Pharmaceutical Sciences 5:8 https://doi.org/10.1186/ s43094-019-0009-6

8. Tatipamula VB, Killari KN, Ketha A, Sastry VG (2017) Taxithelium napalense acts against free radicals and diabetes mellitus. Bangladesh J Pharmacol 12: 197-203 https://doi.org/10.3329/bjp.v12i2.31764

9. Selvam C, Jachak SM (2004) A cyclooxygenase (COX) inhibitory biflavonoid from the seeds of Semecarpus anacardium. J Ethnopharmacol 95:209-212 https://doi.org/10.1016/j.jep.2004.07.026

10. Lee EJ, Kim JS, Kim HP, Lee JH, Kang SS (2010) Phenolic constituents from the flower buds of Lonicera japonica and their 5-lipoxygenase inhibitory activities. Food Chem 120:134-139 https://doi.org/10.1016/j.foodchem.2009. 09.088

11. Owen $\mathrm{PL}$, Johns $\mathrm{T}$ (1999) Xanthine oxidase inhibitory activity of northeastern North American plant remedies used for gout. J Ethnopharmacol 64:149-160. https://doi.org/10.1016/S0378-8741(98)00119-6

12. Tatipamula VB, Killari KN, Prasad K, Rao GS, Talluri MR, Vantaku S, Bilakanti D, Srilakshmi N (2019) Cytotoxicity studies of the chemical constituents from marine algae Chara baltica. Indian J Pharm Sci 81:815-823 https://doi.org/ 10.36468/pharmaceutical-sciences.575

13. Charlier C, Michaux C (2003) Dual inhibition of cyclooxygenase-2 (COX-2) and 5-lipoxygenase (5-LOX) as a new strategy to provide safer non-steroidal anti-inflammatory drugs. Eur J Med Chem 38:645-659. https://doi.org/10. 1016/S0223-5234(03)00115-6

14. Canali R, Comitato R, Schonlau F, Virgili F (2009) The anti-inflammatory pharmacology of Pycnogenol ${ }^{\oplus}$ in humans involves COX-2 and 5-LOX mRNA expression in leukocytes. Int Immunopharmacol 9:1145-1149 https://doi. org/10.1016/j.intimp.2009.06.001

15. Fiorucci S, Meli R, Bucci M, Cirino G (2001) Dual inhibitors of cyclooxygenase and 5-lipoxygenase. A new avenue in anti-inflammatory therapy?. Biochem Pharmacol 62:1433-1438. https://doi.org/10.1016/S0006-2952(01)00747-X

16. Mazumder S, De R, Sarkar S, Siddiqui AA, Saha SJ, Banerjee C, labal MS, Nag S, Debsharma S, Bandyopadhyay U (2016) Selective scavenging of intramitochondrial superoxide corrects diclofenac-induced mitochondrial dysfunction and gastric injury: a novel gastroprotective mechanism independent of gastric acid suppression. Biochem Pharmacol 121:33-51 https://doi.org/10.1016/j.bcp.2016.09.027

17. Gilroy DW, Tomlinson A, Willoughby DA (1998) Differential effects of inhibitors of cyclooxygenase (cyclooxygenase 1 and cyclooxygenase 2) in acute inflammation. Eur J Pharmacol 355:211-217. https://doi.org/10.1016/ S0014-2999(98)00508-1

18. Jäggi R, Würgler U, Grandjean F, Weiser M (2004) Dual inhibition of 5lipoxygenase/cyclooxygenase by a reconstituted homeopathic remedy; possible explanation for clinical efficacy and favourable gastrointestinal tolerability. Inflamm Res 53:150-157 https://doi.org/10.1007/s00011-003-1236-y

19. Martel-Pelletier J, Lajeunesse D, Reboul P, Pelletier JP (2003) Therapeutic role of dual inhibitors of 5-LOX and COX, selective and non-selective nonsteroidal anti-inflammatory drugs. Ann Rheum Dis 62:501-509 https://doi. org/10.1136/ard.62.6.501

20. Dyer RD, Connor DT (1997) Dual inhibitors of prostaglandin and leukotriene biosynthesis. Curr Pharm Des 3:463-472

21. Booth VH (1938) The specificity of xanthine oxidase. Biochem J 32:494 https://dx.doi.org/10.1042\%2Fbj0320494 
22. Ragab G, Elshahaly M, Bardin T (2017) Gout: An old disease in new perspective-a review. J Adv Res 8:495-511 https://doi.org/10.1016/j.jare. 2017.04.008

23. Denoble AE, Huffman KM, Stabler TV, Kelly SJ, Hershfield MS, McDaniel GE, Coleman RE, Kraus VB (2011) Uric acid is a danger signal of increasing risk for osteoarthritis through inflammasome activation. Proc Natl Acad Sci USA 108:2088-2093 https://doi.org/10.1073/pnas.1012743108

24. Pétrilli V, Martinon F (2007) The inflammasome, autoinflammatory diseases, and gout. Joint Bone Spine 74:571-576 https://doi.org/10.1016/j.jbspin.2007. 04.004

25. Edwards NL (2008) Gout. In: Primer on the rheumatic diseases. Springer, New York, pp 241-262

26. Liede A, Karlan BY, Narod SA (2004) Cancer risks for male carriers of germline mutations in BRCA1 or BRCA2: a review of the literature. J Clin Oncol 22:735-742

27. Yang XR, Chang-Claude J, Goode EL, Couch FJ, Nevanlinna H, Milne RL, Gaudet M, Schmidt MK, Broeks A, Cox A, Fasching PA (2011) Associations of breast cancer risk factors with tumor subtypes: a pooled analysis from the breast cancer association consortium studies. J Natl Cancer Inst 103:250-263 https://doi.org/10.1093/jnci/djq526

28. Ferrandina G, Ranelletti FO, Lauriola L, Fanfani F, Legge F, Mottolese M, Nicotra MR, Natali PG, Zakut VH, Scambia G (2002) Cyclooxygenase-2 (COX2), epidermal growth factor receptor (EGFR), and Her-2/neu expression in ovarian cancer. Gynecol Oncol 85:305-310 https://doi.org/10.1006/gyno. 2002.6620

29. Crofford $\amalg$ (1997) COX-1 and COX-2 tissue expression: implications and predictions. J Rheumatol 49:15-19

30. Ye YN, Wu WK, Shin VY, Bruce IC, Wong BC, Cho CH (2005) Dual inhibition of 5-LOX and COX-2 suppresses colon cancer formation promoted by cigarette smoke. Carcinogenesis 26:827-834 https://doi.org/10.1093/carcin/ bgi012

31. Yang HJ, Youn H, Seong KM, Yun YJ, Kim W, Kim YH, Lee JY, Kim CS, Jin YW, Youn B (2011) Psoralidin, a dual inhibitor of COX-2 and 5-LOX, regulates ionizing radiation (IR)-induced pulmonary inflammation. Biochem Pharmacol 82:524-534 https://doi.org/10.1016/j.bcp.2011.05.027

\section{Publisher's Note}

Springer Nature remains neutral with regard to jurisdictional claims in published maps and institutional affiliations.

\section{Submit your manuscript to a SpringerOpen ${ }^{\circ}$ journal and benefit from:}

- Convenient online submission

- Rigorous peer review

- Open access: articles freely available online

- High visibility within the field

- Retaining the copyright to your article

Submit your next manuscript at $\boldsymbol{\nabla}$ springeropen.com 